\title{
Ostatnie lata Profesora Mariana Przełęckiego
}

\author{
Anna Brożek \\ (Uniwersytet Warszawski, Instytut Filozofii)
}

W 2018 roku upłynęło pięć lat od śmierci Profesora Mariana Przełęckiego. Z tej okazji odbyło się w Instytucie Filozofii UW sympozjum poświęcone jego pamięci - zatytułowane Zasięg i granice metod logicznych. Podczas sympozjum referaty wygłosili kolejno: prof. Elżbieta Kałuszyńska, prof. Anna Jedynak, prof. Jacek Jadacki oraz dr Magdalena Matusiak-Rojek, dr Marcin Będkowski i dr Mateusz Pencuła. Część spośród tych referatów ukazuje się właśnie na łamach „Edukacji Filozoficznej”.

Tak się złożyło, że pierwsza trójka spośród wymienionych uczonych to przedstawiciele pokolenia „profesorskiego”, dojrzałego, a druga trójka - to młodzi doktorzy, stojący na początku swojej drogi życiowej i naukowej. Jestem pewna, że Profesorowi Przełęckiemu takie proporcje bardzo by odpowiadały. Cenił sobie bardzo koleżeńskie i przyjacielskie relacje z osobami z kręgu naukowego, do którego należała wspomniana trójka „profesorska”; lubił, gdy jego prace były nie tylko czytane, ale i komentowane w środowisku filozoficznym; chętnie podejmował się polemik.

Podobnie cieszyłby się Profesor Przełęcki z tego, że jego idee są podejmowane przez osoby młode. Kiedyś wspominał, że gdy był wykładowcą w Instytucie Filozofii UW, najchętniej wykładał logikę dla pierwszego roku, czuł bowiem wtedy, że ma duży wpływ na swoich nieukształtowanych jeszcze studentów - na ich kulturę logiczną. Gdy w ostatnich latach życia podejmował problematykę aksjologiczną, także pragnął, aby poglądy przez niego głoszone docierały do młodego pokolenia, które było - jego zdaniem - wystawione na akty agresji ze strony 
współczesnego bezwzględnego świata, tak bardzo różnego od świata, w którym sam wzrastał i którego wartości akceptował.

Profesor Przełęcki urodził się 23 maja 1923 roku w Katowicach. Rozpoczął studia tuż po wojnie w Uniwersytecie Łódzkim, gdzie następnie został asystentem Janiny Kotarbińskiej. Od 1952 roku aż do emerytury był pracownikiem Zakładu Logiki w Instytucie Filozofii Uniwersytetu Warszawskiego. Głównym obszarem jego zainteresowań naukowych była logika formalna i metodologia nauk (tu głównym dziełem Przełęckiego jest The Logic of Empirical Theories - 1969). Począwszy od lat osiemdziesiątych podejmował jednak coraz częściej problematykę aksjologiczną (w 1989 roku wydał Chrześcijaństwo niewierzących).

Przełęcki ostatnie dziesięć lat swojego życia spędził w odosobnieniu - w zakładzie opiekuńczym w Otwocku. Trafił tam wraz z żoną, Aleksandrą, znanym biologiem, gdy ta obłożnie zachorowała. Po śmierci żony w 2005 roku Profesor Przełęcki nie zdecydował się już na opuszczenie Otwocka, chociaż do końca był w pełni sprawny umysłowo i samodzielny fizycznie. Niektórzy namawiali go na powrót do Warszawy - także do aktywniejszego życia naukowego. Profesor Przełęcki wolał jednak pozostać w „otwockiej pustelni”, która zapewniała mu warunki potrzebne do łączenia spokojnej pracy twórczej z codzienną kontemplacją piękna przyrody, muzyki i literatury.

Swoją wizję świata Profesor Przełęcki opisywał wielokrotnie - m.in. w takich słowach:

Ten świat mi się jawi jako „cudowny” i „straszliwy” zarazem. Jego „cudowność" to jego niezwykłe, niewiarygodne piękno; jego „straszliwość” to przepełniający go niewyobrażalny ogrom cierpienia wszystkich istot czujących. Stąd - z jednej strony - zachwyt nad jego pięknem, z drugiej ból i lęk w obliczu istniejącego i grożącego cierpienia (Przełęcki 2011, s. 305).

W Otwocku Profesor Przełęcki na każdym kroku doświadczał przeżyć, które tę wizję świata utrwalały. Przeżył śmierć ukochanej żony i był świadkiem umierania wielu otwockich pensjonariuszy. Zarazem jednak codziennie spotykał się z poświęceniem i oddaniem zakonnic, które cierpieniu swoich podopiecznych próbowały zaradzić, wcielając w życie tak bliski Profesorowi Przełęckiemu ideał miłosierdzia.

W czasie tych dziesięciu otwockich lat Profesora Przełęckiego odwiedzało kilkoro przyjaciół i znajomych, wśród których byłam i ja. Pierwsze moje wizyty 
datują się na okres, gdy podjęłam się wraz z prof. Jadackim redakcji naukowej tomów pism Profesora Przełęckiego - Intuicje moralne (Przełęcki 2005) i Horyzonty metafizyki (Przełęcki 2007). Były to tomy obejmujące rozproszone publikacje, ale udało się nam namówić Profesora Przełęckiego na napisanie kilku tekstów oryginalnych. Wyglądało to tak, że Profesor Przełęcki przesyłał mi rękopisy tych tekstów (pisał zawsze długopisem lub ołówkiem na luźnych kartkach), które przepisywałam na komputerze i odsyłałam do korekty. Za największy owoc otwockich spotkań uważam książkę W poszukiwaniu najwyższych wartości. Rozmowy międzypokoleniowe: zbiór krótkich wypowiedzi uczestników tych spotkań (Profesora Przełęckiego, prof. Jadackiego i moich) na temat takich spraw jak ideał moralny, dobro i zło, sens życia i śmierci itd. (Brożek, Jadacki, Przełęcki 2011).

Ostatnie dwa teksty, które Profesor Przełęcki przekazał mi do przepisania, były najbardziej osobiste. Ukazały się one, zgodnie z życzeniem Autora, już po jego śmierci: jeden na łamach „Edukacji Filozoficznej” (Wyznania politycznego konformisty); drugi - „Kwartalnika Filozoficznego” (Zwierzenia intymne). W pierwszym - Profesor Przełęcki wyjaśnia swoją postawę polityczną; drugi sam nazywał swoją „spowiedzią”, a tłumaczy się w nim (głównie, jak zaznaczał, przed swoimi przyjaciółmi) ze sposobu, w jaki udawało mu się - a niekiedy, jak szczerze przyznawał, nie udawało - realizować głoszone przez siebie postulaty moralne.

Wspominam o tych ostatnich publikacjach Profesora Przełęckiego, gdyż ich tytuły dobrze oddają problematykę, która go w ostatnich latach życia nurtowała. Chociaż tylko swoje prace czysto logiczne uważał za prace naukowe, to w otwockich latach rzadko już do tych prac wracał, tłumacząc się - jak zwykle z ujmującym uśmiechem - że na twórczą pracę w zakresie logiki nie starcza mu już sił intelektualnych. Skądinąd myślę, że powód był inny: jego otwocka perspektywa życiowa kazała mu zwracać się wyłącznie do spraw najważniejszych. O tym zaś, co uważał wówczas za sprawy najważniejsze, pisał m.in. w eseju Sprawy ważne i nieważne:

Ważne w życiu ludzkim ma być w rezultacie nie to, co zewnętrzne, głośne, spektakularne, tylko to, co wewnętrzne, ciche i intymne. W tym właśnie ma się przejawiać prawdziwa wartość tego życia, jego prawdziwy sens (Przełęcki 2011, s. 15). 
W 2018 roku zwrócił się do Profesora Przełęckiego prof. Piotr Gutowski, przewodniczący Komitetu Nauk Filozoficznych PAN, z propozycją udzielenia wywiadu w ramach cyklu „Nestorzy filozofii polskiej”. Ja miałam ten wywiad przeprowadzić. Profesor Przełęcki długo nie chciał się zgodzić na wywiad, zwłaszcza, że wymagałoby to przyjazdu do „otwockiej pustelni” ekipy filmowej, która przecież do „pustelni” nie pasowała. Ostatecznie udało mi się namówić Profesora Przełęckiego na rozmowę przed kamerą - pod warunkiem, że odbędzie się ona tylko w mojej obecności. Wiosną 2018 roku wzięłam więc swoją amatorską kamerę filmową i pojechałam do Otwocka. Ustawiłam ją na statywie, włączyłam - i długo rozmawialiśmy: ja pytałam, a Profesor Przełęcki odpowiadał. Wywiad został opublikowany - i mówiono mi, że słowa wypowiedziane przez Profesora Przełęckiego zrobiły na internetowej publiczności przejmujące wrażenie.

Nie wiedziałam wtedy, że widzę się z Profesorem Przełęckim po raz ostatni. Parę miesięcy później dostałam wiadomość o pogorszeniu jego stanu zdrowia. Profesor Przełęcki prosił zawsze, by go nie odwiedzać, gdy czuje się słabo. Uszanowałam i wtedy tę prośbę. Zmarł 8 sierpnia. Profesor Przełęcki - niewierzący chrześcijanin, jak się sam określał - mawiał, że modli się inaczej, niż to jest w suplikacji: że prosi o nagłą i niespodziewaną śmierć. Martwił się czasem, że ma mocne serce - bo to mu owej nagłej śmierci nie wróżyło. Obawiał się umierania powolnego, w bólu - ale ostatecznie odszedł bez nadmiernych cierpień. Miał 90 lat i był na śmierć przygotowany. Szkoda tylko, że nie zobaczył imponującej księgi pamiątkowej, przygotowanej z okazji jubileuszu. Wiedział jednak o niej i znał wiele podarowanych mu w niej tekstów.

Na końcu wspomnianego wyżej wywiadu zapytałam Profesora Przełęckiego, czy jest jakaś jego ważna myśl, którą chciałby, żebyśmy my - jego czytelnicy szczególnie zapamiętali. Odpowiedział w sposób dla siebie bardzo charakterystyczny:

Pani Aniu! nikt nie będzie niczego kojarzył z moim nazwiskiem, bo o mnie zapomni natychmiast. Ja nie jestem twórcą żadnej nowej idei filozoficznej. Opowiadam się za taką a nie inną, ale niczego nowego nie stworzyłem. Kiedy zapytano Einsteina, jaki ma sposób na notowanie myśli, odpowiedział: „Myśl - to taka rzadka rzecz". Więc ja żadnej myśli nie znalazłem i nie martwię się o to, z czym mnie będą kojarzyć... 
W ciągu ostatnich lat życia Profesora Przełęckiego bardzo się ze sobą zżyliśmy. Ponieważ nie tylko redagowałam tomy jego prac, lecz także obcowałam $\mathrm{z}$ ich treścią. Śmierć Profesora Przełęckiego przerwała nasze spotkania, ale coś ze „wspólnoty dusz” pozostało - bo do jego pięknych i sugestywnych wizji metafizycznych i etycznych nie sposób nie wracać, kiedy się je raz poznało. Gdybym to ja miała odpowiedzieć na pytanie o jego najważniejszą myśl - to byłaby to parafraza znanego zwrotu (cenionego przez Profesora Przełęckiego) Fiodora Dostojewskiego: Nawet jeśli Boga nie ma, to nasze czyny mają wartość, a nasze życie ma sens.

\section{Bibliografia}

Brożek A., Jadacki J., Przełęcki M. (2011), W poszukiwaniu najwyższych wartości. Rozmowy międzypokoleniowe, Warszawa: Wydawnictwo Naukowe Semper.

Brożek A., Jadacki J. (red.) (2014), Nauka i język. Seria druga. Księga pamiątkowa Marianowi Przełęckiemu $w$ darze na 90-lecie urodzin, Lublin: Wydawnictwo Norbertinum.

Przełęcki M. (1969), The Logic of Empirical Theories, London: Routledge \& Kegan Paul.

Przełęcki M. (1989), Chrześcijaństwo niewierzących, Warszawa: Czytelnik.

Przełęcki M. (2005), Intuicje moralne, red. A. Brożek, J. Jadacki, Warszawa: Wydawnictwo Naukowe Semper.

Przełęcki M. (2007), Horyzonty metafizyki, red. A. Brożek, Warszawa: Wydawnictwo Naukowe Semper. 